\title{
THE QUANTITATIVE ESTIMATION OF ETHICS: THE REGIONAL AND NATIONAL INDEX OF ETHICS [THE ETHICS PERCEPTION INDEX (ETPI)]
}

\author{
Alexander SHEMETEV ${ }^{\mathrm{a}}$ \\ a Prague University of Economics and Business, email: alexandershemetev@gmail.com
}

Cite this article: Shemetev, A. (2021). The quantitative estimation of ethics: the Regional and National Index of Ethics [The Ethics Perception Index (ETPI)]. Deturope. 13(3), 73-97.

\begin{abstract}
Ethics do not appear from the vacuum. Researchers estimate ethics intuitively. At the same time, there is no quantitative approach for measuring the overall background of ethics in the community. This research aims to present a quantitative process for measuring the general level of ethics in societies.

This research aims at presenting a quantitative index of ethics. Researchers can quickly reproduce the results of this index, and it grants the understandability of its main components and the potential for applications. The suggested global index of ethics (ETPI - Ethics Perception Index) creates the basis for further quantitative analysis of the levels of ethics in each region of different countries by RETPI (Regional ETPI). This paper suggests it is crucial to apply a quantitative measure of ethics that is valid for countries and regions.

It is the first global and regional index of ethics, upon the best we know. The basis for the estimation of the ethics index is the evaluation of the components related to corruption, economic freedoms, human development, education, human rights, and environmental issues (the depletion of natural resources and other parameters). In addition, this research represents the method for an ordinal estimation of the level of ethics within different subregions. Such evaluation allows comparing different countries and regions in terms of the development of ethics. It is the first global and regional index of ethics, upon the best we know.
\end{abstract}

Keywords: the regional index of ethics, the national index of ethics, development of ethics, ethics, ETPI, RETPI, ethics perception index, quantitative estimation of ethics, social and economic background of ethics

\section{INTRODUCTION}

Ethics do not appear from the vacuum. Researchers estimate ethics intuitively. The overall background forces to form all the branches of ethics in society. At the same time, there is no quantitative approach to measuring the comprehensive background of ethics in the community. This research aims to present a quantitative process for measuring the general level of ethics in societies.

This research aims at presenting a quantitative measurement of ethics, and it grants the understandability of its main components and the potential for applications. The suggested global index of ethics (ETPI - Ethics Perception Index) creates the basis for analyzing the levels of ethics in each region of different countries (RETPI - Regional ETPI). Researchers can 
quickly reproduce the results of this index. This paper suggests it is crucial to apply a quantitative measure of ethics that is valid for countries and regions.

The basis for the estimation of the ethics index is the evaluation of the components related to corruption, economic freedoms, human development, education, human rights, and environmental issues (the depletion of natural resources and other parameters). In addition, this research represents the method for an ordinal estimation of the level of ethics within different subregions. Such evaluation allows comparing different countries and regions in terms of the development of ethics. It is the first global and regional index of ethics, upon the best we know.

\section{THEORETICAL BACKGROUND}

The basis of many types of research is quantitative analysis. For example, a data-based approach is vital to confirm or disprove some concept or hypothesis. For instance, economics apply quantitative research and data from the middle of the XX century (Kuznets, 1941; Kuznets, 1941; Smith, 1942). The development of these tools allows for macroeconomic (Doepke et al., 1999; Williamson, 2018) and microeconomic (Perloff, 1998) forecasting. At the same time, economists often separate ethics from other disciplines from the very first works in this field (Smith, 1761; Smith, 1998). Different approaches on ethical issues divided the researchers on political economists (Cameron et al., 1994; Mandeville, 2011; Rayman \& Rayman, 2019; Ricardo, 2005; A. Smith, 1776), and other schools, like, for example, Marxists (Marx, 1867, 2015; Marx et al., 2012; Rjazanov, 1928; Roth et al., 2017). Nevertheless, quantitative indicators often prevailed in choosing the proper ways of economic development. For example, Keynesian economists prove the necessity of governmental interventions based on standard logic and, later, on data (Beckhart \& Keynes, 1936; Hein \& Lavoie, 2019; Roberts, 1995; Sims et al., 2020). The other example is that many prominent researchers applied a similar approach based on common logic and data for proving or disproving their concepts (Friedman, 1995; Stiglitz, 2005).

At the same time, there were no quantitative indicators of ethics. The ethical issues often came either from logic (Hardin \& Hayek, 1989; Hayek \& Bartley, 2013) or from the common sense of the borders of ethics ${ }^{7}$.

\footnotetext{
${ }^{7}$ Prominent researchers (De Mel et al., 2008; Fuchs-Schündeln et al., 2015) describe typical examples of the experiments in economics. A narrow part of population receives some economic resource. Researchers analyze what people do with this exogenous resource. Large-scale experiments could prove any theory much better. In a perfect case, these would be random countries receiving random governments, social structures, and "treatments"; at the same time, such experiments are highly unethical (C. A. Sims, 2010). The computer-run experiments (like, for example, (Heinemann \& Noussair, 2015)) are not a perfect remedy as well. People might behave differently in real life than in a computer-run environment. The population selection is another shortcoming of this approach.
} 
On the other hand, ethics is a multidisciplinary phenomenon. It is vital for medicine, law, human rights, public administration (for example, ethical corruption issues), economics, education, and the environment. Researchers never applied a unified method for quantitative estimation of ethics at the global and regional levels, upon the best we know. The gap in the current state of knowledge in ethics became the reason for performing this research. This paper aims to prove and present an understandable index of ethics while minimizing any potential political context or subjectivism. The primary purpose of this research is to represent the designed global and regional indexes of ethics in a multidisciplinary field.

\section{BACKGROUND FOR ADOPTING THE METHODOLOGICAL APPROACH}

\section{The Main Components of the Index of Ethics}

It is the preliminary part of the analysis of ethics. This part discusses the potential roots of ethics in a region, country, and society. For example, there are cannibal tribes that consider eating people as a highly virtuous deed. At the same time, many other nations would consider this unethical. This part aims to discuss the sources of ethics in each region, country, and society. There is no unified international code of ethics for everything. For example, there is no united approach even to such widely-discussed ethical problems as euthanasia (Ebrahimi, 2012; Fernandes, 2001; Narbekovas \& Meilius, 2004). That is why the "root" of ethics might be more important to understand than the "branches."

That is why the research of the roots of ethics is urgent. Some psychologists (Bloom, 2013; Bloom \& Cook, 2013) interpret ethics as an innate understanding of "right" and "wrong"; babies aged above three months have this inner feeling of ethics, these researchers suggest. The inborn genes driven by the environment form the ethical patterns of the "good" and "evil" practices by stimulating the "proper" behavior with the maximum potential benefits for this individual and the local society (Bloom, 2013).

Therefore, it is probable that every human acquires ethical patterns from the environment that modifies her inner feelings of ethics. Thus, a person gradually learns ethics; fig. 1 represents the sources of ethics. 
Figure 1 The suggested concept of the sources of ethics

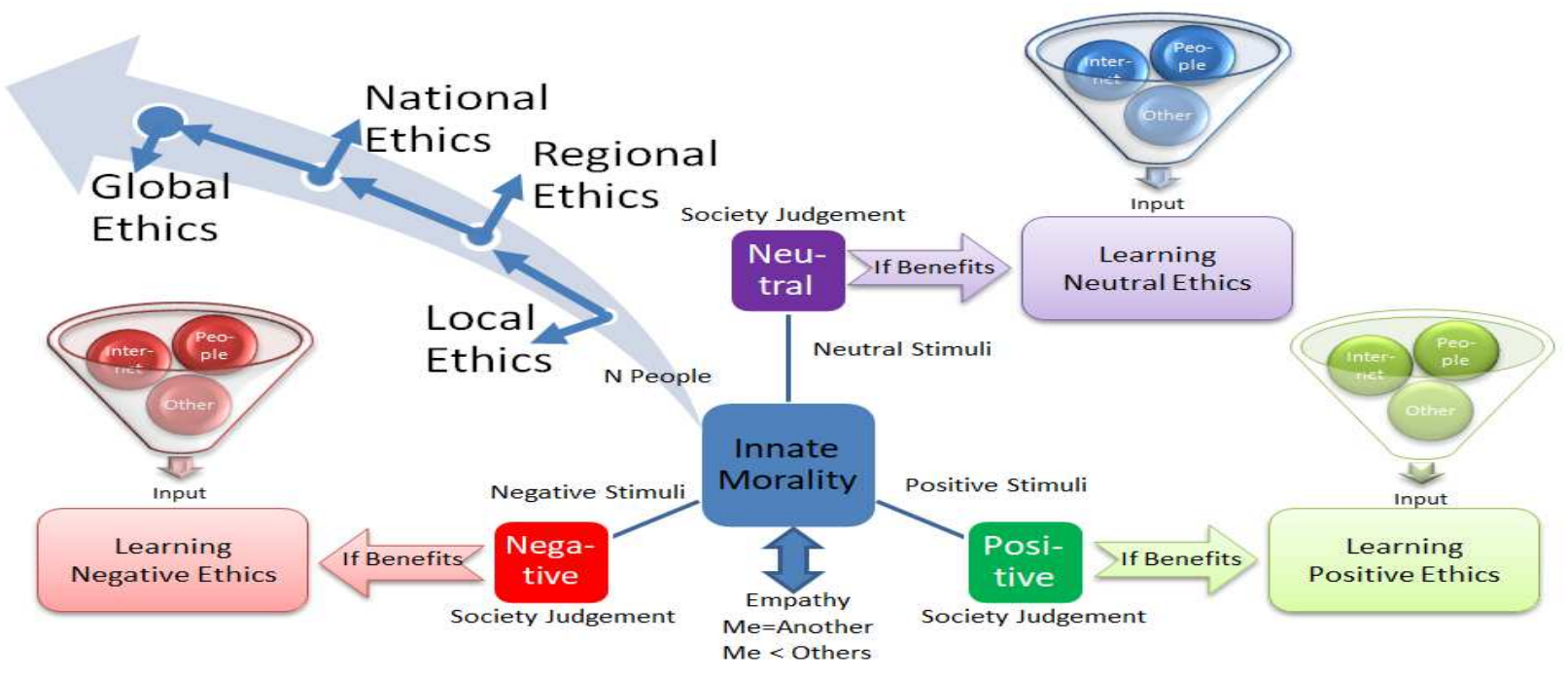

Source: Own processing

Thus, ethics looks like a stochastic process, as seen from figure 1. It originates from the fact that the number of directions is endless for developing innate morality into the collective ethic over time. The borders of the development of ethics from inherent characteristics are, thus, extremely wide. For example, some tribes might think of cannibalism as ethical; others might think of human sacrificing as a moral issue. Figure 2 represents this concept in more detail.

Figure 2 The suggested concept of ethics formed by education ${ }^{8}$

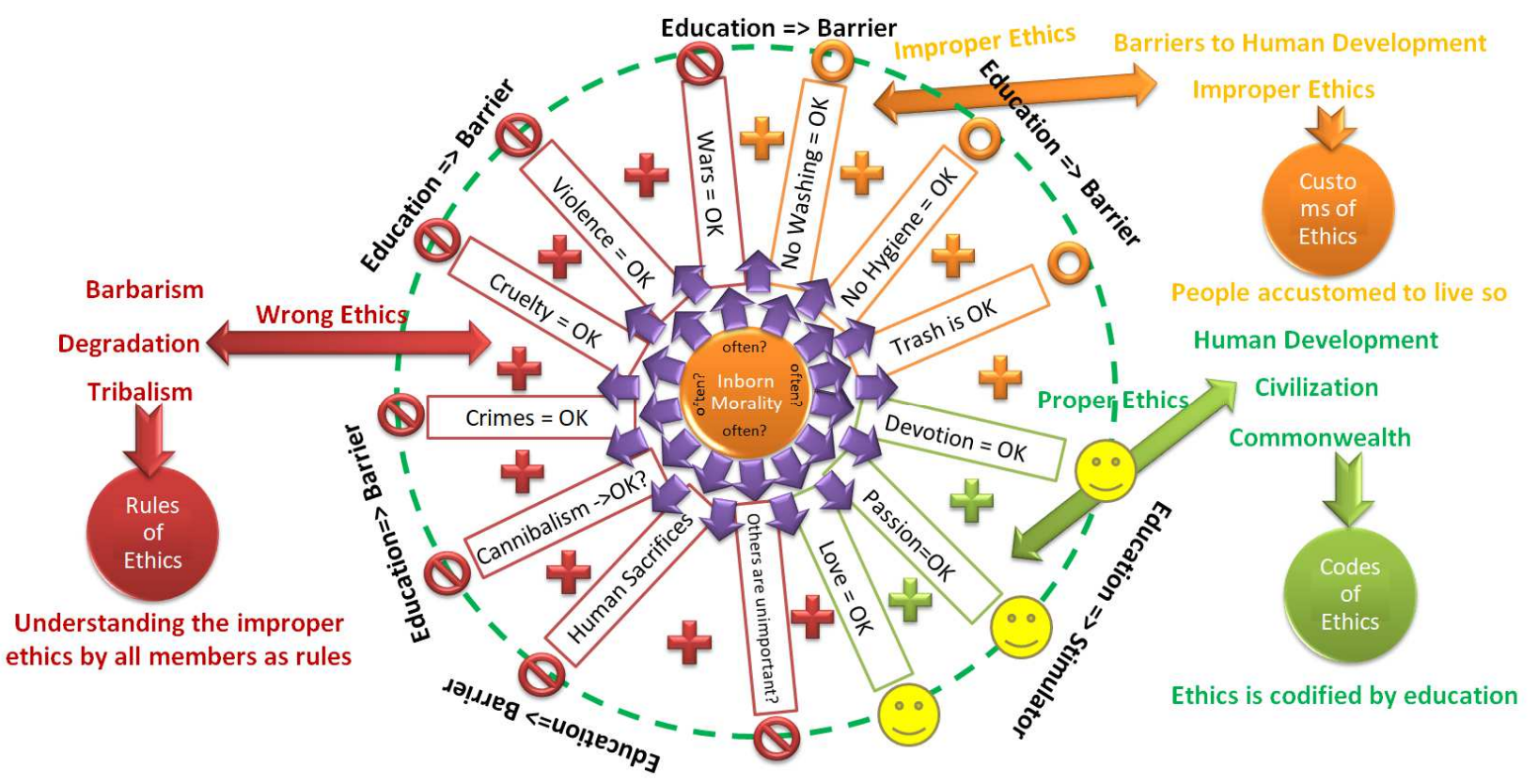

Source: Own processing

\footnotetext{
${ }^{8}$ The further development of education gradually explains each sphere in more detail. For example, love is a good feeling (widely understandable). But further development of education gradually calibrates its understanding. It starts to dig deeper into each category, like love to what - to children, to patronymic, to murders, to marginalism, to harassment? Thus, education gradually calibrates ethics even further. It starts to explain in more detail which love is ethical and which is not. The same logic is valid for all the values.
} 
Thus, education creates a barrier for selecting the mechanisms for proper ethics; it removes the patterns that might be highly unethical. Education is a sort of filter for selecting "good" and "bad" practices (from the ethical side). The globalization of education creates the globalized filter for the best ethical practices. For example, slavery was an essential source of capital for many companies, regions, and even for some nations. People explained slavery as a common phenomenon coming from the deep roots of society (ancient world, medieval times, and, partially, in renaissance and the new times). The development of education distributed the concept that slavery is highly unethical. It made the society abandon slavery on all official levels (with some minor exceptions in some countries ${ }^{9}$ and regions).

Therefore, education creates the foundation for understanding ethics. Education can explain that some phenomena are ethically "bad." It can also explain why some practices are morally improper. For example, some wild tribes can practice cannibalism, human sacrifices, or similar things; these people might not know that such practices are unethical. Moreover, such tribes might consider similar negative phenomena as a high manifestation of the norms of ethics of this society, growing them up from early childhood. Proper education can distinguish the correct ethical standards and, thus, stimulate the development of a community. It can also teach people to abandon unethical norms.

In addition, nations tend to codify basic ethical principles. These codes describe the desired outcomes of different scenarios of unethical behavior. For example, a criminal code explains the consequences of corrupt conduct against individuals. A country can call itself "constitutional" only if it bases its regulations on the highest ethical standards and norms. Otherwise, it could be just a country of law ${ }^{10}$, in the best case. People might consider fair and well-structured legislation as a written code of ethics.

At the same time, there is no direct way for comparing the legislation of different countries (or regions) in some cases. For example, there is no unified definition of even such standard terms as "government" so that all the nations and people would ideally agree with this definition. Thus, this research suggests that understanding ethics by the formal written statutes might lead to the impossibility of comparing ethical standards on a national and regional level. That can become possible in the future with computing and data analysis tools ${ }^{11}$.

At the same time, education can become a far better tool than just legislation in ethics research. It forms the apperception of ethical standards in the whole society. For example, some

\footnotetext{
${ }^{9}$ For example, Mauritania (it will gradually come to normal condition with the development of education, this study suggests).

${ }^{10}$ "Country of law“ - is a nation that follows its legislative norms in resolving different issues no matter how ethical these statutes are. For example, law can prescribe burn the witches, and the "country of law" can follow it. However, constitutional state would never apply such a law, even if it would exist in its legislation somehow, because it is unethical. The most primitive form of the "country of law" is the "country of customs", when the oral or written customs become laws no matter how ethical they are in reality.

${ }^{11}$ There should be some algorithm that would be capable to read the legislation of all nations and regions and compare it on the highest professional level possible, on the one hand, and the practice of its implication, on the other hand.
} 
laws might be unethical. On the other hand, violating some ethical rules is not an offense by law. An educated society understands ethics: it can impose moral penalties on individuals/firms/officials who disrespect ethical norms. These moral punishments can range from disapproving views (or remarks) to a complete boycott by the entire community.

Education is an essential tool for evaluating the development of ethical standards. The progress of science enriches education. Scientific discussions create suitable materials for students that improve their understanding of the world and, partially, form their ethics. The highly advanced education can shift the behavior of the entire society in a proper direction. For example, trading with slaves was widespread in many countries a few centuries ago. Russia, for instance, abandoned slavery in 1861. Most of Russia's population were slaves for centuries before that date (Troinitsky, 1858).

Another example is the Thirteenth Amendment that officially abandoned slavery in the USA in 1865. Education development explains why certain phenomena (like slavery) are unethical. Better education allows taking a fresh look at certain phenomena and estimating them from the ethical position. Thus, proper education creates a solid barrier against all unethical standards in all spheres.

\section{The Discussion about the Potential Indexes of Ethics}

There are many ethical indexes globally (mainly in the financial sphere). For example, there is a range of Dow Jones Sustainability Indices (DJSI). These indexes list the firms with high ethical standards (Carlos \& Lewis, 2018; Chatterji et al., 2016; Lee \& Faff, 2009). At the same time, these indexes are about the financial sphere to exclude unethical firms from the lists (Johnson, 2013; Rodgers \& Rodgers, 1989; Standard Ethics, 2021).

At the same time, ethical standards do not exist at the financial markets solely to be measured by the indexes. Ethics is a global phenomenon, and it regulates society in many dimensions: cultural, spiritual, social, economic, political, and technological. Ethics might vary in different cultures in various geospatial units (like regions, countries, nations). Thus, analysts should not measure ethical standards within several large companies only.

Moreover, substantial multinational companies can have headquarters far from the actual places where they earn their money. For example, some companies can have the US as the primary source of their profits. At the same time, its headquarters might be somewhere in Ireland, Bermuda, Barbados, Panama, or any other "financial paradise." Thus, it is unclear if its high ethical standards belong to the US, Bermuda, Barbados, Panama, or other countries. How should we share the high ethics of such companies within numerous countries they might exist? Can society estimate its ethics by the standards of ethics at financial markets? This research 
suggests the concept that ethics is a broad phenomenon. At the same time, we did not find any quantitative ethics indexes on regional and national levels, upon the best we know. The gap in the current state of knowledge became the reason and the motivation of this research.

Another approach is an attempt to estimate the levels of freedoms (Fundación para el Avance de la Libertad, 2019). It is a relatively new approach. It estimates freedoms (that is close to ethics (Fundación para el Avance de la Libertad, 2019)). This approach estimates five categories: religion, bioethics, drugs, sex, and family/gender. An ideal country should have free faith, abortions, minimally controlled drugs, free sex, and easy approaches to family and gender. The measurement of these characteristics is expert-based and, thus, is highly subjective. For example, Afghanistan is at the end of this rating in 2020. However, this country can be among the most accessible places on the planet to take drugs, probably, more accessible than at the leader of the rating of 2020 - the Netherlands (Varlamov, 2021a, 2021c, 2021b). Thus, 1/6 of the local component of freedom can be of a high value in 2020 (even though the lowest total rating). The absence of a transparent and reproducible quantitative basis for estimating such indices doesn't allow researchers to reproduce calculations and assess any potential bias. In addition, that approach (Fundación para el Avance de la Libertad, 2019) estimates a person as a rational consumer who maximizes her utility by consuming a more comprehensive range of commodities provided by the broader freedoms that make her life easier. At the same time, these authors measure the levels of ethics and freedoms beyond the questions of corruption, ecology, healthcare, education, depletion of natural resources, and many more.

This paper suggests another approach for estimating ethics. This research estimates ethics as a quantitative measure, and it applies an analysis of the ethical background in a region or a nation as a whole. This way of thinking is new in scientific literature, upon the best we know. Accordingly, the proposed method forms a unique index.

\section{DATA AND METHODS}

The first step is obtaining the data. This research utilizes seven components to estimate the ethics perception index: corruption perception index [CPI] (Bevir \& Letki, 2012; Heide, 2020; Lambsdorff, 2017; Transparency International, 2020), economic freedom index [EFI] (Fraser Institute, 2021), education index (EI) (United Nations Development Programme, 2021a), human development index [HDI] (UNDP, 2020), human rights score index [HRS] (Our World in Data, 2020), Natural resource depletion (\% of GNI) (Our World in Data, 2020; United Nations Development Programme, 2021b; World Bank, 2020), environmental performance index (Conrad \& Cassar, 2019; Wendling et al., 2020). 
The next necessary part is an explanation of each of the indicators.

\section{The first component of the index of ethics is CPI}

Figure 3 Corruption perception index as a tool for evaluation of ethics
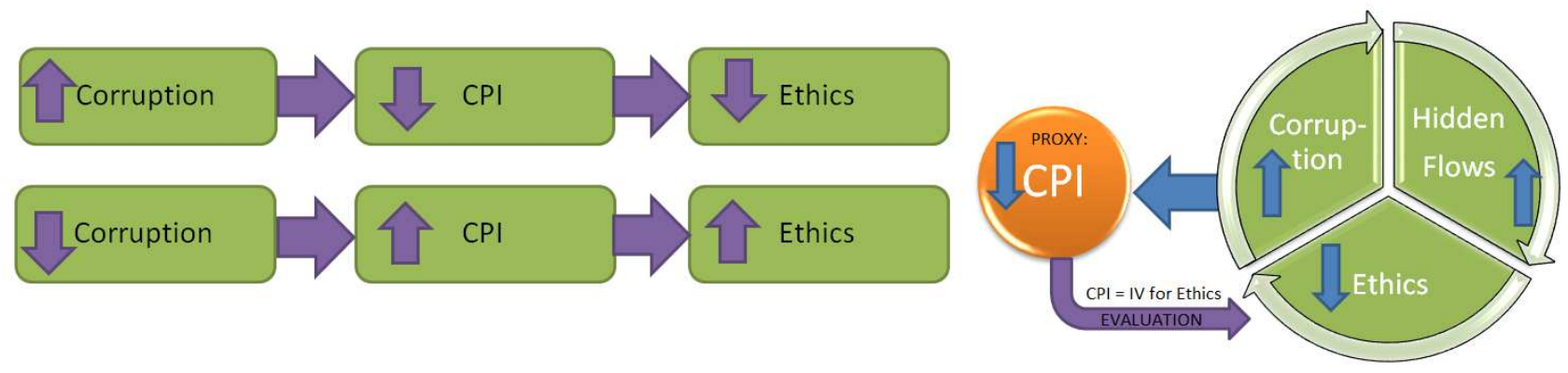

Source: Own processing

Since corruption is a secret process that involves hidden flows, there is no way to establish an accurate level of corruption. The best variant available today is the corruption perception index. This index is an input for one of the seven components of the ethics index proposed in this paper. The corruption perception index is a kind of proxy for the variable of the actual state of affairs with corruption. Corruption depends on ethics. The higher the ethical standards accepted in society, the less room for corruption is left. Legal mechanisms are an insufficient measure to defeat corruption.

Moreover, there may be a high level of corruption in many strong states with a total control system. The level of corruption does not depend much on the intensity of the justice system ${ }^{12}$; it depends on the norms of ethical principles that society accepts. The effectiveness of anticorruption justice largely depends on ethics, which explains the importance of the first component of the ethics index.

This research suggests an assessment of the CPI based on relative scales. A country with the highest corruption index has $100 \%$ (the higher the index, the better the situation with corruption). This procedure standardizes the variables included in the ethics index so that the contribution of each of the seven components stays uniform. Since the corruption index is more of an ordinal measure than a cardinal one, this index compares countries and nothing more. Therefore, the conversion of indices to relative scales preserves the essence of the index as an ordinal measure. This research performed similar transformations for other indices that do not have the meaning of a cardinal measure.

The second component of the index of ethics is the economic freedom index (EFI).

${ }^{12}$ For example, many totalitarian regimes had strict justice systems and high levels of corruption. 
Figure 4 EFI as a tool for evaluation of ethics

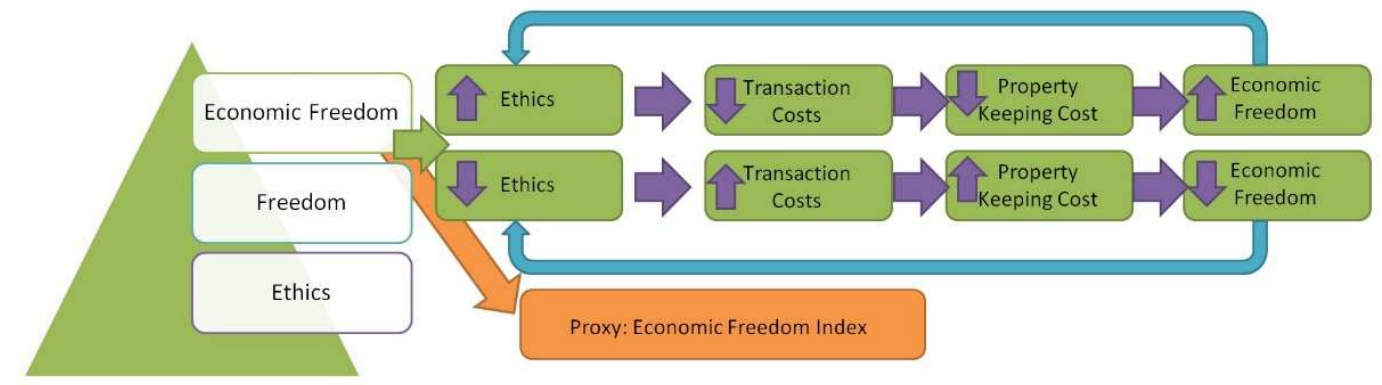

Source: Own processing

The interaction of economic freedom and ethics is endogenous. The growth of economic freedom leads to better ethics. Improved ethics reduce transaction costs of maintaining the property. Better ethics make it easier to predict the behavior of different agents. As a result, this reduces transaction costs. It decreases the cost of maintaining property rights (and related rights). An owner can spend less on specialists and means to protect property rights if the level of ethics in society is high. The development of economic freedom relates to the level of ethics in the community. If society considers it ethical to restrict any market freedoms and economic freedoms, then the level of ethics in such a society is not high enough yet. Education (as a barrier and as a reference point) does not effectively guide the development of ethical laws in such countries. The index of economic freedom is a proxy of the actual level of economic freedom in a country. This research supposes rescaling this index in relative values at 100 percent of the maximum value in the world. It makes it possible to track indices on comparable scales.

\section{The third component of the index of ethics is the education index (EI).}

Figure 2 indicates that education is a significant barrier and benchmark for the quality development of ethics. Education development makes it possible to explain the benefits and disadvantages of recognizing the ethics of various actions, inaction, and elements at the new level. The education index is the closest proxy variable to the level of education. This research evaluates the education index on relative scales of 100 percent of the highest value in the world. The fourth component of the index of ethics is the human development index (HDI). 
Figure 5 HDI as a tool for evaluation of ethics

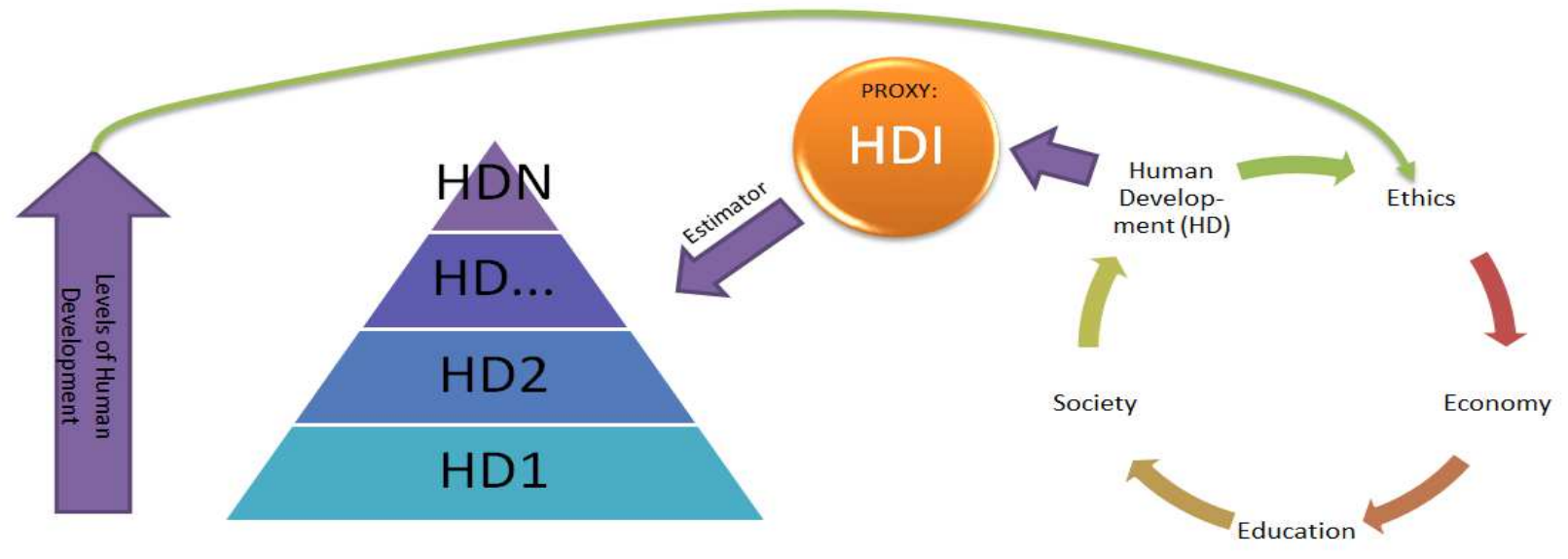

Source: Own processing

Almost every person on the planet holds tremendous potential for development. Nevertheless, potential and its application can be completely different concepts. Some people with enormous potential may not learn to read and write for the rest of their lives, while others with less initial potential can develop it to an almost limitless size. The average level of human development can stimulate or hinder human potential in a country. The quality of HD [human development] is endogenously related to the quality of development of ethics, economics, education, and society. The higher the average level of human development in the country, the higher the level of development of ethics, economy, education, and community. Higher levels of development of ethics, economics, education, and society lead to a higher level of human development. Thus, HD can become a valuable tool for analyzing the quality of ethics developed in the community. The closest proxy to human development is the Human Development Index. Nations can distinguish different levels of human development around the globe (within the framework of this index). The higher the average level of human development, the higher the level of development of ethics in society. This research evaluates HDI on relative scales of 100 percent of the highest value in the world.

The fifth component of the index of ethics is the human rights score (HRS).

Figure 6 HRS as a tool for evaluation of ethics; HR - human rights

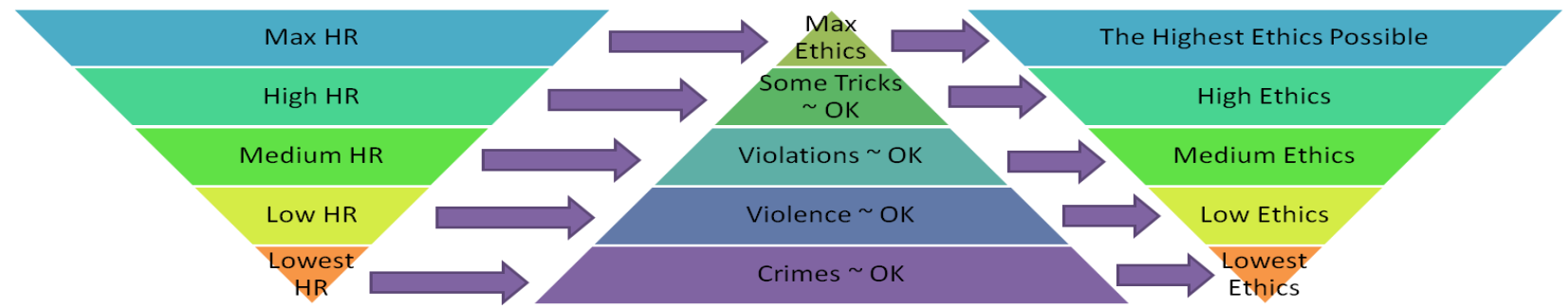

Source: Own processing 
A low level of human rights means that a wide range of crimes can be committed against an individual or a group of people and can stay unpunished. Such societies may regard even serious crimes as common ethical phenomena. The understanding of ethics grows with the development of human rights. The higher the level of human rights, the fewer offenses (and crimes) against people and property will stay without severe consequences for those who committed them. Researchers can perceive penal codes as the minimum standards of ethics in a country. If the level of human rights is high, then the quality of regulations and codes at the legislative level will also be increased. As a result, ethics itself will be high. Some people will comply with the law because they will consider it ethical. Another part of the people will comply with the law because they will be afraid of punishment. The higher the level of development of human rights, the more inevitable the punishment for criminals and violators will be, the more ethical the laws and officials who execute them will be, and the more people will join high norms and standards of ethics. This research evaluates HRS on relative scales of 100 percent of the highest value in the world.

\section{The sixth component of the index of ethics is natural resource depletion [NRD] (percentage of GNI).}

Figure 7 Natural resource depletion (NRD) as a tool for evaluation of ethics

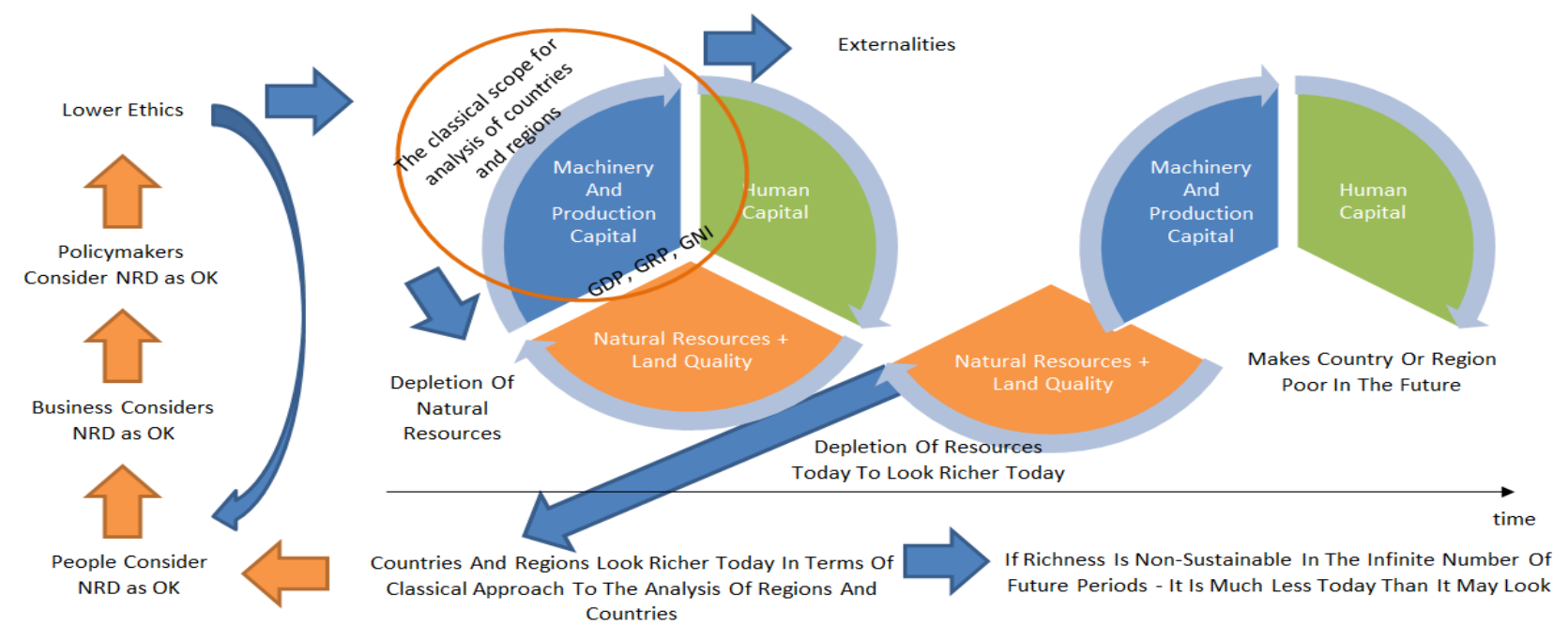

Source: Own processing

The depletion of natural resources for the sake of economic development may indicate a relatively lower level of ethics. Many non-ethical things are possible due to the tacit consent of society. If society does not accept significant volumes of deforestation, depletion of natural resources, then this indicates a sufficiently high level of ethics in the community. Any country may seem richer today due to the use of resources, that is, in fact, due to tomorrow, when these resources will no longer exist. The higher the degree of depletion of natural resources, the worse 
for the nation it is. For comparison, the percentage of depletion of natural resources is estimated in relation to the gross national income. For all other indicators of the ethics index, the higher the value of the index, the better the situation is. The opposite is true for this component. Therefore, the following formula translates the NRD indicator into the same scale with other indices $^{13}$.

$\mathrm{NRDh}_{\mathrm{i}}=100 *\left(1-\mathrm{NRD}(\% \text { of GNI })_{\mathrm{i}}\right)$

The seventh component of the index of ethics is the environmental performance index (EPI).

Figure 8 Environmental performance index (EPI) as a tool for evaluation of ethics

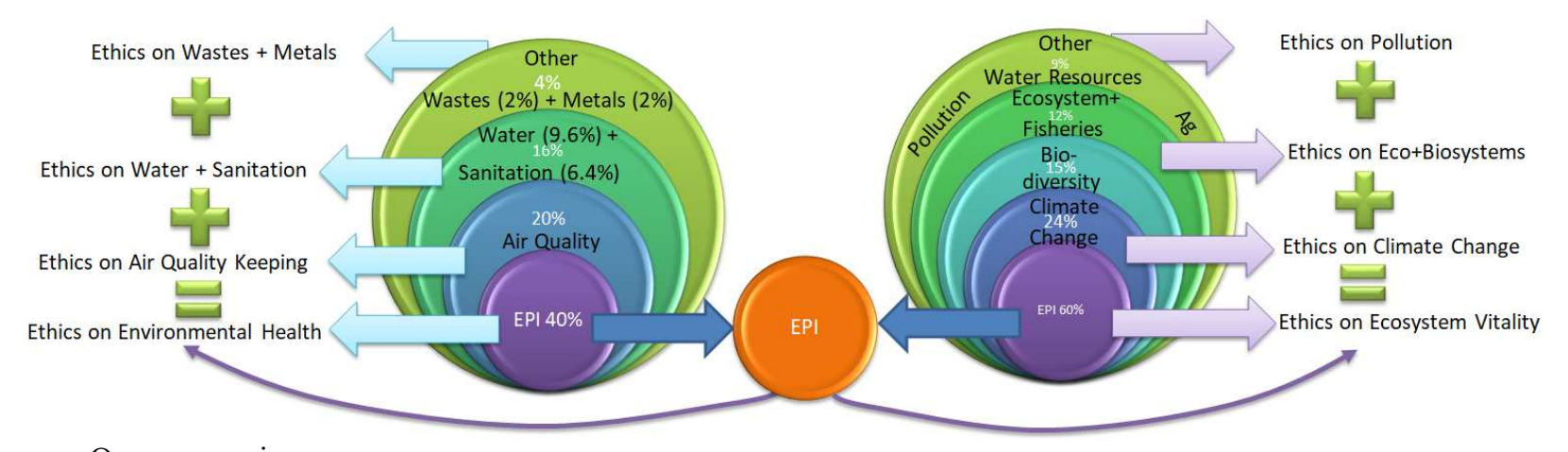

Source: Own processing

An important manifestation of ethics (in modern economics) is society's attitude towards environmental protection. The more ethical the community is, the better is the attitude towards the environment. Suppose society considers it righteous to throw garbage on the streets, exterminate whole species of animals and plants, and dispose of toxic waste in its territories. In that case, the level of ethics in such societies cannot be high. Low levels of ecology also hurt human health, which is contrary to generally accepted categories of ethics and morality. An essential and most comprehensive indicator of the state of the ecological system in a country is the environmental performance index (EPI). It consists of about 1400 fundamental ecological indicators. This index is reassessed based on a relative rating scale of $100 \%$ of the maximum value in the world so that all indices included as components of the general ethics index have a comparable rating scale.

\section{The discussion on the practice of averaging the components of indexes}

The modern indexes are usually either a simple or weighted average of partially numerical and partial qualitative indicators. Some indices apply methods based on discriminant analysis

\footnotetext{
${ }^{13} \mathrm{NRDh}$ - the intermediary indicator for the NRD for the i-th country; NRD - natural resource depletion (percentage of GNI) of the i-th country.
} 
(Fisher, 1936; Gorban et al., 2018) to estimate the overall index. It is practical to count and calculate these values to acquire composite indexes (like CPI, EPI, education index, and many more). Its algorithm is comparable to determine the average value - researchers take some indicators and apply discrimination coefficients to assess the overall value (for example, EPI). Although there are some opposing sides to this approach, it makes it possible to estimate the overall levels of different indices. No better tool exists today for evaluating comprehensive indexes at national levels. Our research applies a similar approach for assessing the general index of ethics on a national level. There is no better way (up to today) to evaluate the unified level of ethics and reveal its main components to represent why some country is more advanced in ethics than others. Thus, this research assumes equality of all the variables that compose the ETPI index. In addition, this research suggests that any potential multicollinearities ${ }^{14}$ of the original components of the ETPI are insignificant since there is no better tool for measuring ethics.

\section{The main components of the index of ethics}

The first step is estimating the indexes' relative grading (RG). The formula for the CPI (corruption index):

$$
C P I_{i}^{R G}=\frac{100 * C P I_{i}^{L D}}{\max \left(C P I^{L D}\right)}
$$

Such an approach to the relative grading follows from the standard logic of proportions:

$$
\begin{array}{cc}
\operatorname{Max}\left(X^{L D}\right) & 100 \% \\
X_{i}^{L D} & Y_{i} \%
\end{array} \Rightarrow X_{i}^{L D} * 100 \%=\operatorname{Max}\left(X^{L D}\right) * Y_{i} \% \Rightarrow Y_{i} \%=\frac{X_{i}^{L D} * 100 \%}{\operatorname{Max}\left(X^{L D}\right)}
$$

Notations: $C P I_{i}^{R G}-\mathrm{CPI}$ of the i-th country with relative grading; $C P I_{i}^{L D}$ - CPI of the i-th country on the last date known; $\max \left(C P I^{L D}\right)$ - is the maximum value ${ }^{15}$ of the CPI for the last date known.

The formula for the EFI (economic freedom index):

$$
E F I_{i}^{R G}=\frac{100 * E F I_{i}^{L D}}{\max \left(E F I^{L D}\right)}
$$

Notations: $E F I_{i}^{R G}-$ EFI of the i-th country with relative grading; $E F I_{i}^{L D}$ - EFI of the i-th country on the last date known; $\max \left(E F I^{L D}\right)$ - is the maximum value of the EFI for the last date known.

\footnotetext{
${ }^{14}$ This term here means the possibility that some component of ethics might partially describe part of another component (for example, connections between education and human development).

${ }^{15}$ The maximum value for all indices is the global greatest value (within the set of all countries) for the last date known. LD means „last date“; it can be some retrospective value for the potential historical analysis.
} 
The formula for the EI (education index):

$$
E I_{i}^{R G}=\frac{100 * E I_{i}^{L D}}{\max \left(E I^{L D}\right)}
$$

Notations: $E I_{i}^{R G}-\mathrm{EI}$ of the i-th country with relative grading; $E I_{i}^{L D}$ - EI of the i-th country on the last date known; $\max \left(E I^{L D}\right)$ - is the maximum value of the EI for the last date known.

The formula for the HDI (human development index):

$$
H D I_{i}^{R G}=\frac{100 * H D I_{i}^{L D}}{\max \left(H D I^{L D}\right)}
$$

Notations: $H D I_{i}^{R G}-$ HDI of the i-th country with relative grading; $H D I_{i}^{L D}$ - HDI of the i-th country on the last date known; $\max \left(H D I^{L D}\right)$ - is the maximum value of the HDI for the last date known.

The formula for the HRI (human rights index):

$$
H R I_{i}^{R G}=\frac{100^{*} H R I_{i}^{L D}}{\max \left(H R I^{L D}\right)}
$$

Notations: $H R I_{i}^{R G}-\mathrm{HRI}$ of the $\mathrm{i}$-th country with relative grading; $H R I_{i}^{L D}-\mathrm{HRI}$ of the $\mathrm{i}$-th country on the last date known; $\max \left(H R I^{L D}\right)$ - is the maximum value of the HRI for the last date known.

The formula for the NRD (natural resource depletion, after the formula (1)):

$$
\operatorname{NRDh}_{i}^{R G}=\frac{100 * \mathrm{NRDh}_{i}^{L D}}{\max \left(\mathrm{NRDh}^{L D}\right)}
$$

Notations: $\mathrm{NRDh}_{i}^{R G}-\mathrm{NRDh}$ of the i-th country with relative grading; $\mathrm{NRDh}_{i}^{L D}-\mathrm{NRDh}$ of the $\mathrm{i}$-th country on the last date known; $\max \left(\mathrm{NRDh}^{L D}\right)$ - is the maximum value of the NRDh for the last date known.

The formula for the EPI (environmental performance index):

$$
E P I_{i}^{R G}=\frac{100 * E P I_{i}^{L D}}{\max \left(E P I^{L D}\right)}
$$

Notations: $E P I_{i}^{R G}-$ EPI of the i-th country with relative grading; $E P I_{i}^{L D}-$ EPI of the i-th country on the last date known; $\max \left(E P I^{L D}\right)$ - is the maximum value of the EPI for the last date known.

The ethics perception index [ETPI] formula:

$$
E T P I_{i}=\frac{E P I_{i}^{R G}+\mathrm{NRDh}_{i}^{R G}+H R I_{i}^{R G}+H D I_{i}^{R G}+E I_{i}^{R G}+C P I_{i}^{R G}+E F I_{i}^{R G}}{7}
$$


The weighting of each index component can create future modifications of this index (10). This research does not implement any weighting for the ethics perception index.

\section{Processing the missing data}

Any of the seven indices may be unavailable on the most recent date at specific points in time. This research applies the five-year intervals in assessing the ethics index for data processing purposes. This research implements the data as of the latest date where data for the world's countries is available. If newer data (that is more recent) comes out, the ETPI becomes more up-to-date (it updates the value of the index). A similar process, in particular, occurs when assessing many macroeconomic indicators. For example, governmental agencies and national statistical offices can recalculate such indicators as GDP within the next five years due to the incoming new data and processing. This research represents the algorithm for estimating the missing data in the table below.

Table 1 The process for evaluating the missing data

\begin{tabular}{|c|c|c|c|c|c|}
\hline Indicator & 2017 & 2018 & 2019 & 2020 & 2021 \\
\hline CPI & & & & LD & \\
\hline EFI & & LD & & & \\
\hline EI & & & LD & & \\
\hline HDI & & & LD & & \\
\hline HRI & LD & & & & \\
\hline NRD & & $\mathrm{LD}$ & & & \\
\hline EPI & & & $\mathrm{LD}$ & & \\
\hline & \multicolumn{5}{|c|}{ The data is missing (it will appear as soon as it is available; the ETPI values will become updated then) } \\
\hline & \multicolumn{5}{|c|}{ The data is valid for this year } \\
\hline $\mathrm{LD}$ & \multicolumn{5}{|c|}{ The last data available for the calculation of the index; LD - last data available } \\
\hline
\end{tabular}

Source: Own processing

This study suggests that it is best to implement the data without transformations. Artificial analysis or prediction of the index value may not be a tool for qualitative improvement of the analysis. This study processes the missing data as it becomes available. The upcoming new data on the components of the ETPI gradually updates the values of the resulting ethics index (as new data becomes available). Some elements of the ethics index are complex enough; there is no way to assess and report them quickly. For example, the human rights index (HRI) estimates data available after a significant time. This research designs the index of ethics (ETPI) to avoid any artificial data modifications; ETPI processes the missing data as soon as it becomes available. 


\section{Estimating the ETPI (index of ethics) for the regions within each country: regional ETPI (RETPI)}

Unfortunately, CPI, EFI, EPI, NRD, EI, HDI, and HRI have no estimations on the regional levels, and we can only estimate them on the national level. Hence, it is possible to receive ETPI on the national level only. This national-level indicator has some score valued " $\mathrm{X}$ " within each country (i). It can be interpreted as $100 \%$ because ETPI and its derivative (regional ethical index, RETPI) is ordinal, but not cardinal measure; it allows comparing different countries and regions on the level of ethics.

The RETPI method assumes that people learn data through the internet. The internet is gaining more and more popularity as a medium for finding the necessary information on various topics, including ethics. This research utilizes data from search engines. The unique algorithm in the programming language $\mathrm{R}$ designed for this research obtains the data. If we take the Earth as a whole, then the most popular search engine in the world is Google (arguably). The popularity of Google is increasing, mainly due to the growth in the number of mobile devices globally. Many mobile devices use the Android operating system that the Google Corporation develops. This system has an in-built search from Google and many services from Google. Some users of other mobile devices also use Google search (as well as other Google services). Therefore, Google search trends can serve as a proxy variable for ethics-related queries worldwide. Google has different versions for mobile devices, personal computers, laptops, and other systems. In addition, a significant part of the Google search queries comes from programming languages (without using browsers and other methods).

This study suggests that Google is an essential global provider of trended data given the above. The aggregate ethics index (the regional index of ethics) is derived from the Google search data by category. A researcher can receive proxy variables and latent variables for further analysis.

This research created an algorithm for extracting global data on various categories related to ethics. This algorithm converts the data into a matrix that includes the regions of the country and interest in ethics for specific dates (usually, the first date is the beginning of January 2004, and the end date is the present [unless another time range is not necessary for this algorithm]). 
Figure 9 The suggested concept of ethics that can be captured by searching the information over the internet (usually, by googling it)

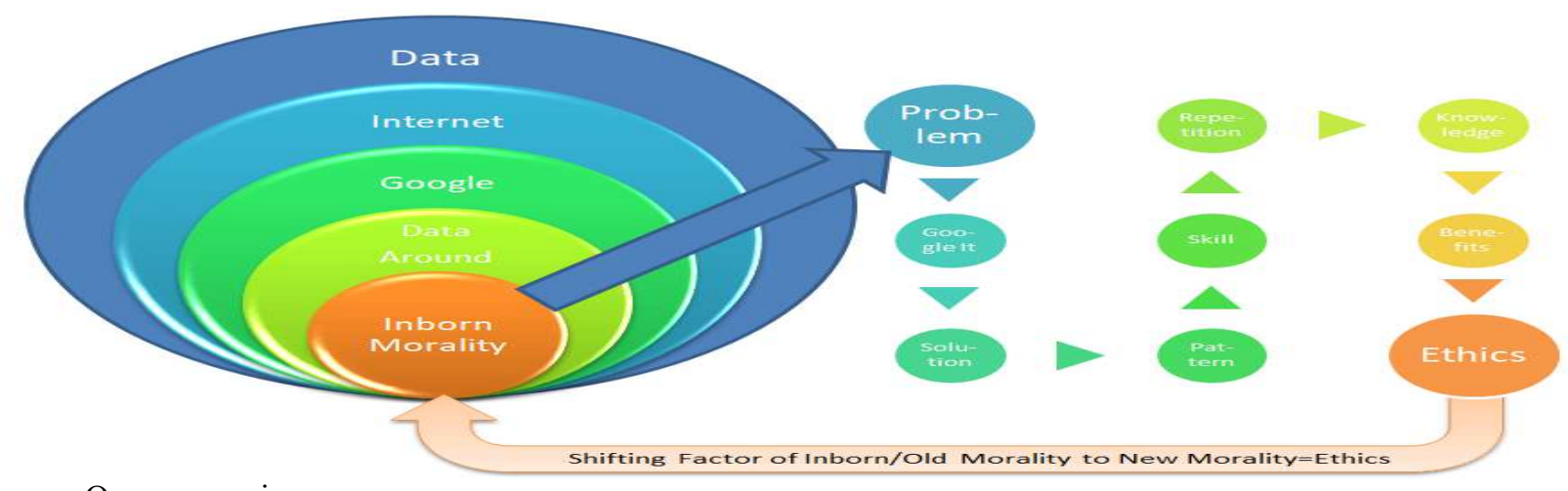

Source: Own processing

Therefore, ethics do not always guarantee a shift in innate morality in the right direction. Individuals gain specific benefits by solving various problems by acquiring data and skills that they can obtain from their data environment.

Considerable attention is paid to data privacy when using unloads from Google systems (search, images, video, and news). The researcher may want data about each individual and their needs. At the same time, such data will not be confidential. The approach proposed in this study implements depersonalized data; this research implements the data on trends instead of the information on levels ${ }^{16}$.

Moreover, this research created several modifications to the $\mathrm{R}$ code. These modifications enrich the set of potential operations with the data. For instance, these codes visualize the data by creating different plots of the interests of the population of other regions and countries at different periods for ethics. This data is a proxy for the time series analysis.

In addition, part of the country's population might be outside their country while studying ethics. Therefore, if a researcher takes the Czech Republic, the country's people speak the Czech language. Acquiring queries made in this language worldwide can distinguish almost all people who study ethics in their native Czech language. Thus, it is possible to single out a general index of the development of ethics for all Czech people, reflecting all trends in the change in interest in ethics.

Higher public interest in ethics probably encourages politicians and businesses to be more interested in ethics. The increased demand for ethics-driven politicians and companies improves ethics systems in enterprises and the country. Improving the ethics system is possible through the legislative consolidation of ethical norms or publishing local regulations, thus, stimulating additional public interest in ethics. Conversely, a decrease in the public interest in ethics reduces the pressure on politicians and businesses and, therefore, can halt positive changes in ethics

${ }^{16}$ The maximum value is $100 \%$ for the day/month/year and region with the highest requests. It ensures maximum data privacy. The absolute maximum is one observation point from each search query. 
development. As a result, this research provides a valuable tool for obtaining time-series data of interest in ethics in a particular region or country. Fig. 10 and 11 represent an example of the relative grading of the areas of Russia (the regional index of ethics).

Figure 10 The expected relative grading of ethics in terms of RETPI for the Russian regions (example), 2021 (short-term instant look on February 2021) ${ }^{17}$

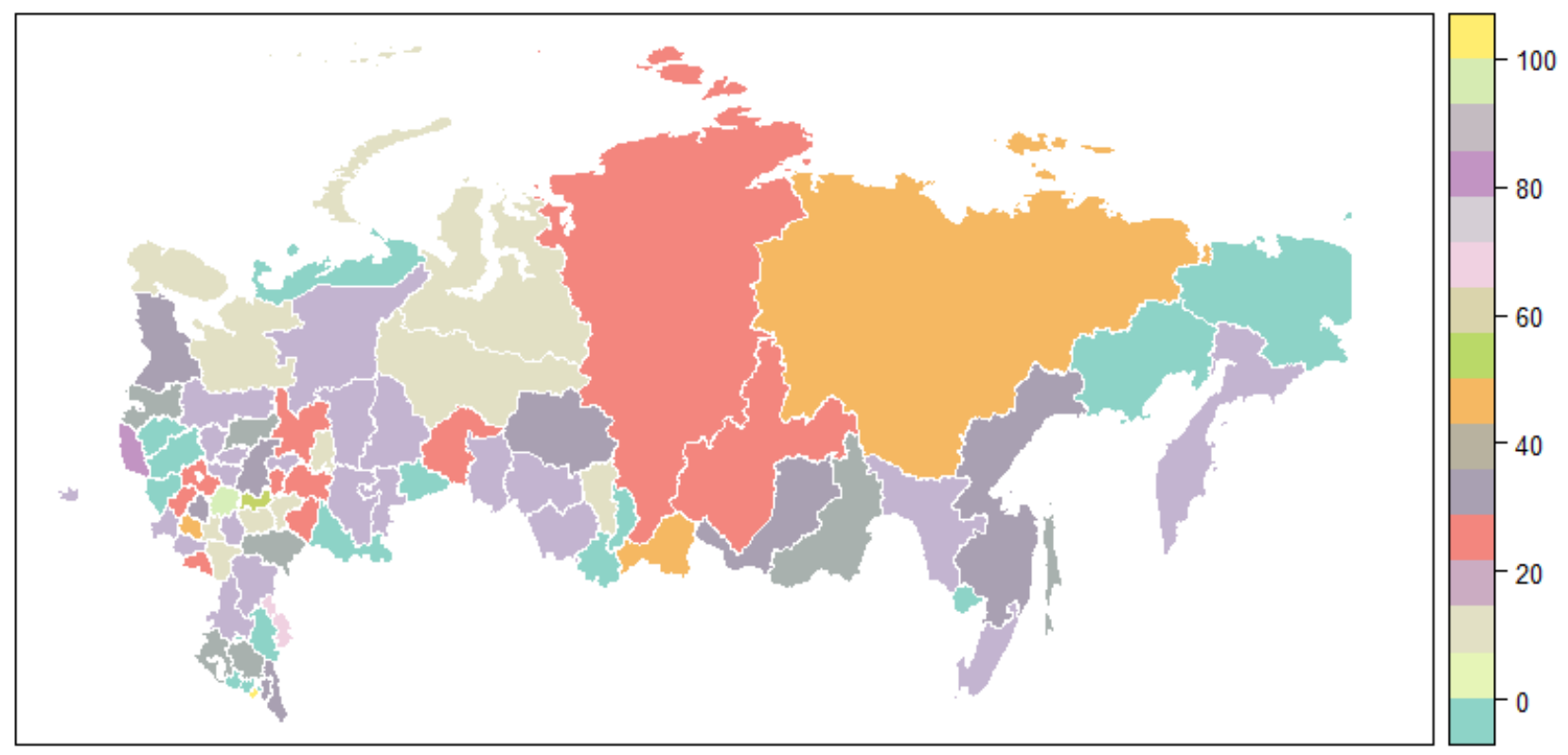

Source: Own processing, the code for estimation for all areas of the globe will soon be available at $\mathrm{R}$ package (Shemetev, 2020)

Figure 11 The expected relative grading of ethics in terms of RETPI for the Russian regions (example), 10/10/2020-10/10/2021

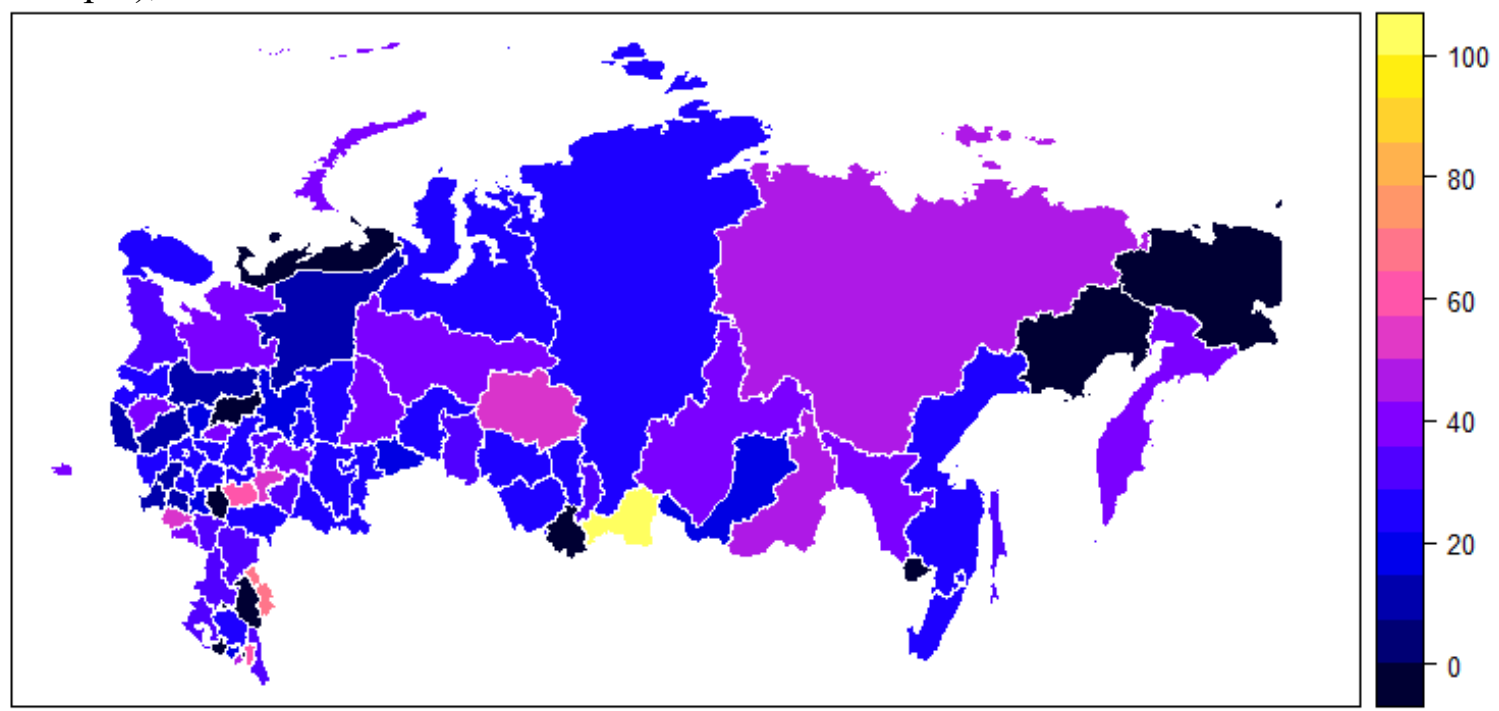

Source: Own processing, the code for estimation for all areas of the globe will soon be available at R package (Shemetev, 2020)

${ }^{17}$ For example, the most ethical region of Russia in February 2021 can be North Ossetia (\#1) [instant RETPI]. But Tuva region is \#1 in an annual term [annual RETPI, October 2020 - October 2021]. 
We understand such an approach has shortcomings related to the scope of individuals learning ethics from other sources than Google/Yahoo/Social networks and similar media. At the same time, not all the regions might have stable internet access to look for new knowledge on ethics-related issues (see, for example, the Chukotka region or far-north regions of Russia in figures 10 and 11). At the same time, the lack of stable internet in some areas in the XXI century provides some information for the relative grading of regions in terms of ethical issues. The population size is not a barrier for estimating ethics. For example, the most ethical part of Russia in 2021 can be Tuva (\#1) and Astrakhan (\#2) [both areas have populations below the top-25 in Russia]. Tuva can have the highest level of instability (according to the number of crimes or economic development). Still, it has the highest positive trends in the interest of ethics over the internet. People there want to learn higher ethical standards and improve their lives in the future. This study suggests that the positive trend in ethics is an essential component for proper regional development. The RETPI index can capture this trend (daily, weekly, monthly, or annually). Tuva and Astrakhan regions are not as populated as Moscow ${ }^{18}$ and SaintPetersburg ${ }^{19}$. The resulting RETPI is not cardinal but an ordinal measure that only compares the areas in terms of ethics by a proxy ${ }^{20}$. It is the first tool for qualitative estimation of ethics on the national and regional basis for comparisons. Estimating this variable brings a valuable regional proxy tool for assessing the relative interest in ethics within the country's regions.

\section{RESULTS AND DISCUSSION}

It is challenging to split economic from ethics; that is why the first thoughts in applying the macroeconomic indicators (Kuznets, 1941; Kuznets, 1941; Smith, 1942) should be continued by adding ethics. It will improve today's classical mathematical tools for calculating and forecasting macroeconomic (Doepke et al., 1999; Williamson, 2018) and microeconomic (Perloff, 1998) phenomena. Splitting the ethics from the economy (famous from the first works in economics ( Smith, 1761; Smith, 1998)) leads to biased estimators.

For example, some countries can be economically more prosperous by applying unethical tools of development (mass violations of human rights, depletion of natural resources, corruption, oppressing economic freedoms, diminishing human development, preventing modern knowledge and education, and spoiling ecology). The possibility of such a development raises criticism toward economics as a science (Eichner, 1983). The idea that everybody might

\footnotetext{
${ }^{18} \# 23$ of 83 in ethics and \#1 in population

${ }^{19} \# 21$ of 83 in ethics and \#4 in population

${ }^{20} \mathrm{It}$ is possible to estimate the regional index from daily to 5 -year period basis (any term).
} 
pursue his interests and be selfish will cause equilibrium by the market's invisible hand (Cameron et al., 1994; Mandeville, 2011; Rayman \& Rayman, 2019; Ricardo, 2005; Smith, 1776); but valid market mechanisms demand high standards of ethics. It is more profitable to deviate from the ethical behavior for economic agents, thus, transferring the costs to the third parties and enjoying benefits. Estimation of ethics in economics should become a lighthouse for the proper financial practices.

Moreover, the core ethics of the economy is not a dispute on whether market or any other type of economy is better or worse (Beckhart \& Keynes, 1936; Friedman, 1995; Hardin \& Hayek, 1989; Hein \& Lavoie, 2019; Marx, 1867, 2015; Marx et al., 2012; Rjazanov, 1928; Roth et al., 2017; Stiglitz, 2005). The principle of economics should be to foster growth and combat crises by the highly ethical tools implemented. The seven components of the ETPI are an effective tool to capture the ethical practices of each nation, not the economic schools that prevail. This estimation minimizes the potential bias of subjectivism: the index assesses the seven macro-fields of ethics, not the economic (political, religious, or other) approaches and concepts applied in a specific region or country.

\section{The national index of ethics}

Figure 12 Ethics perception index, national level (period: 2017-2021)

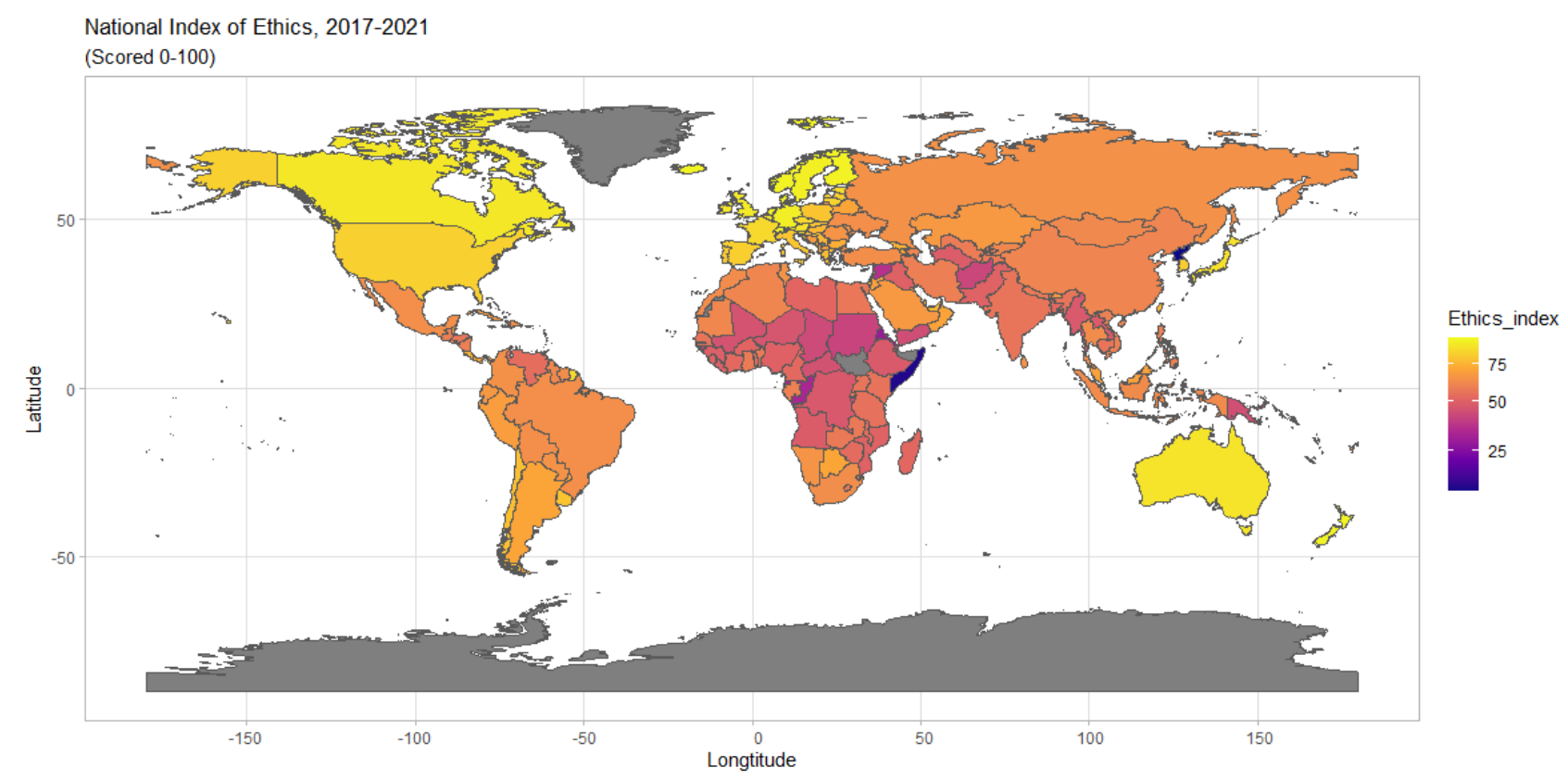

Source: Own processing

The minimum value of the ethics index is 11.01 ; the maximum value is 95 . The median value is 57.66 ; the mean value is 59.85 . 
Figure 13 Top 12 lowest ETPI countries ${ }^{21}$ (period: 2017-2021)

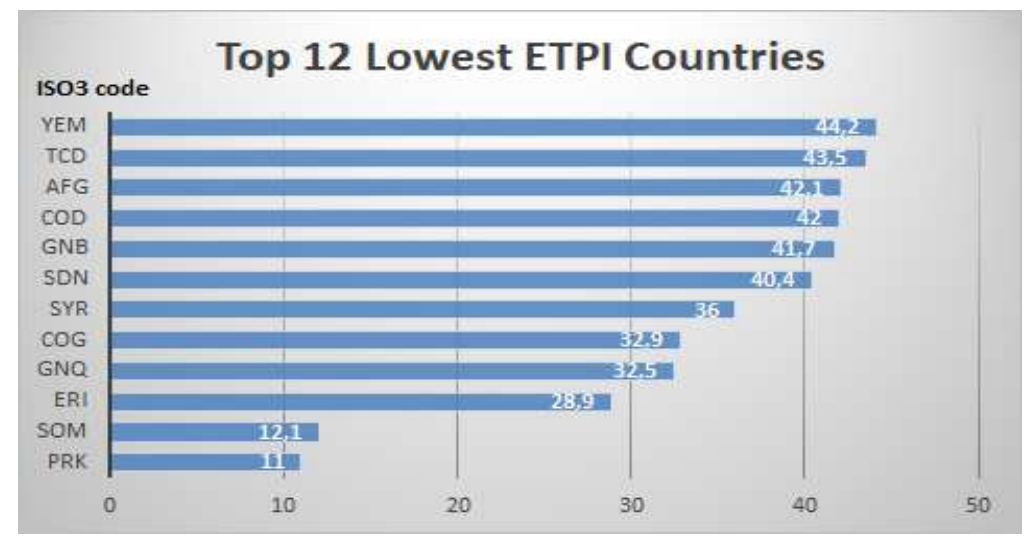

Source: Own processing

Figure 14 Top 15 highest ETPI countries (period: 2017-2021)

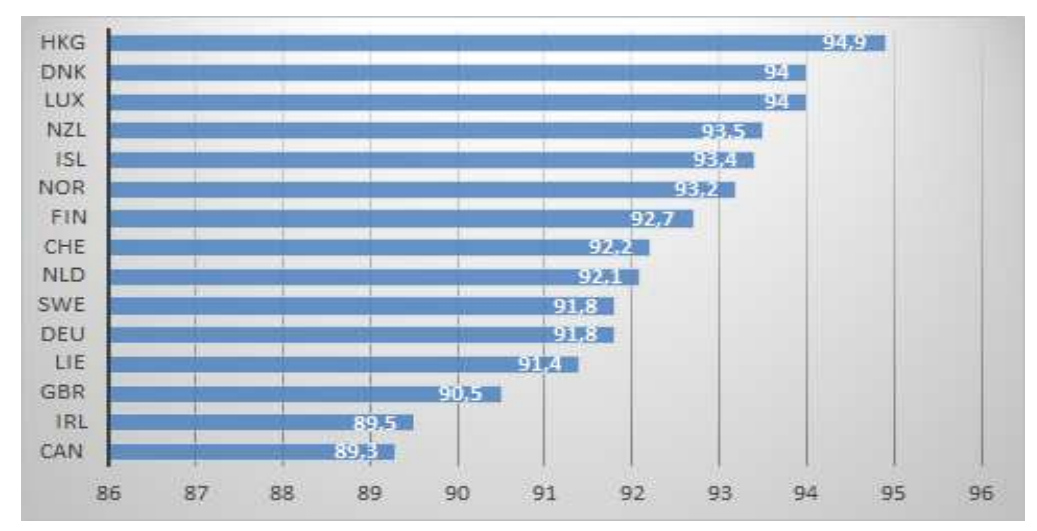

Source: Own processing

The USA is within the top-30 ethical countries globally (ETPI 83 [2017-2020]); its neighbors are the Czech Republic, South Korea, Spain, and Lithuania. Russia is in the top-100 countries in terms of ethics with a value of 64.6 (its neighbors are Colombia, Ukraine, Mexico, and Tunisia). Although China is within the top-122 ETPI countries (ETPI 61), its semiautonomous region Hong Kong is top \#1 in the global ethics within all countries. Some other regions of this country are still developing in terms of ethics; they have a unique regional example of the top-ethics, which reveals multiple perspectives in the rapid ethical development of China in the XXI century. The ETPI index covers 194 countries; 193 countries are official UN members. The data for 47 units (that pretend to be officially recognized as countries [not UN-members]) does not exist (usually, these are small geographical units associated with other more prominent countries). The regional ETPI index can estimate the level of ethics within those territory units.

\footnotetext{
${ }^{21}$ ISO3 code represents the names of the countries
} 


\section{CONCLUSION}

Finance is the main branch for quantitative estimation of ethics nowadays. At the same time, ethical standards do not solely exist in the financial markets. Ethics is a global phenomenon, and it has many dimensions: cultural, spiritual, social, economic, political, ecological, and technological. Ethics might vary in different cultures in various geospatial units (like regions, countries, nations).

The other attempts to measure ethics components (like an estimation of the levels of freedoms) are too narrow and subjective. In addition, it is almost impossible to reproduce any computations and conclusions of such assessments. Thus, there was no transparent way for measuring ethics as a complex phenomenon for different countries and regions.

We achieved the core aim by creating and proving a global index of ethics in its main aspects within each country (ETPI - Ethics Perception Index). We reached the additional objective by providing a tool for estimating each country's ethics at the regional level (RETPI - Regional ETPI). This study focuses on the quantitative elements of ethics. It is crucial to have a quantitative indicator of ethics valid for each country as a whole (and potentially - to its regions under certain assumptions).

The ETPI index reveals the overall indicator from the components of ethics (corruption, economic freedom, human rights, environment, human development, education, and natural resource depletion). It is the first overall global and regional ethical index, and researchers and analysts can widely apply it.

\section{Acknowledgment}

The project funded this research has a number 19/2021 (IG507011, Faculty of Economics, Prague University of Economics and Business [VSE, Czech Republic]).

\section{REFERENCES}

Beckhart, B. H., \& Keynes, J. M. (1936). The General Theory of Employment, Interest and Money. Political Science Quarterly. https://doi.org/10.2307/2143949

Bevir, M., \& Letki, N. (2012). Corruption Perceptions Index. In Encyclopedia of Governance. https://doi.org/10.4135/9781412952613.n110

Bloom, P. (2013). Just Babies: The Origins of Good and Evil. Crown. https://doi.org/10.1080/03057240.2014.923134

Bloom, P., \& Cook, G. (2013). The Moral Life of Babies. Scientific American. https://www.scientificamerican.com/article/the-moral-life-of-babies/

Cameron, K., Rabelais, F., \& Frame, D. M. (1994). The Complete Works of Francois Rabelais. The Modern Language Review. https://doi.org/10.2307/3735180

Carlos, W. C., \& Lewis, B. W. (2018). Strategic Silence: Withholding Certification Status as a 
Hypocrisy Avoidance Tactic. Administrative Science Quarterly, 63(1), 130-169. https://doi.org/10.1177/0001839217695089

Chatterji, A. K., Durand, R., Levine, D. I., \& Touboul, S. (2016). Do ratings of firms converge? Implications for managers, investors and strategy researchers. Strategic Management Journal, 37(8), 1597-1614. https://doi.org/10.1002/smj.2407

Conrad, E., \& Cassar, L. F. (2019). The Environmental Performance Index. In Routledge Handbook of Sustainability Indicators. https://doi.org/10.4324/9781315561103-19

De Mel, S., McKenzie, D., \& Woodruff, C. (2008). Returns to capital in microenterprises: Evidence from a field experiment. Quarterly Journal of Economics, 123(4), 1329-1372. https://doi.org/10.1162/qjec.2008.123.4.1329

Doepke, M., Lehnert, A., \& Sellgren, A. (1999). Macroeconomics. In Macroeconomics. University of Chicago.

Ebrahimi, N. (2012). The ethics of euthanasia | Australian Medical Student Journal. https://www.amsj.org/archives/2066

Eichner, A. (1983). Why Economics Is Not Yet a Science. Journal of Economic Issues, 17(2), 507-520. https://www.jstor.org/stable/4225324?seq=1

Fernandes, A. K. (2001). Euthanasia, assisted suicide, and the philosophical anthropology of Karol Wojtyla. Christian Bioethics, 7(3), 379-402. https://doi.org/10.1076/chbi.7.3.379.6878

Fisher, R. A. (1936). The Use of Multiple Measurements in Taxonomic Problems. Annals of Eugenics, 7(2), 179-188. https://doi.org/10.1111/j.1469-1809.1936.tb02137.x

Fraser Institute. (2021). Economic Freedom of the World: 2020 Annual Report. https://www.fraserinstitute.org/studies/economic-freedom-of-the-world-2020-annualreport

Friedman, M. (1995). A Monetary and Fiscal Framework for Economic Stability. In Essential Readings in Economics. https://doi.org/10.1007/978-1-349-24002-9_19

Fuchs-Schündeln, N., Hassan, T. A., Acemoglu, D., Hsieh, C.-T., Nün, N., Vishny, R., Wiederholt Leonhard Czerny, M., Gorea, D., \& Xu, P. (2015). Natural Experiments in Macroeconomics *.

Fundación para el Avance de la Libertad. (2019). World Index of Moral Freedom. In Liberty. https://fundalib.org/wp-content/uploads/2016/04/World-Index-of-Moral-Freedomweb.pdf

Gorban, A. N., Golubkov, A., Grechuk, B., Mirkes, E. M., \& Tyukin, I. Y. (2018). Correction of AI systems by linear discriminants: Probabilistic foundations. Information Sciences, $466,303-322$.

Hardin, G., \& Hayek, F. A. (1989). The Fatal Conceit: The Errors of Socialism. Population and Development Review. https://doi.org/10.2307/1972446

Heide, M. (2020). Corruption Perceptions Index. In The Palgrave Encyclopedia of Interest Groups, Lobbying and Public Affairs. https://doi.org/10.1007/978-3-030-13895-0_76-1

Hein, E., \& Lavoie, M. (2019). Post-Keynesian economics. In The Elgar Companion to John Maynard Keynes. https://doi.org/10.4337/9781788118569.00097

Heinemann, F., \& Noussair, C. (2015). Macroeconomic experiments. Journal of Economic Studies, 42(6). https://doi.org/10.1108/JES-09-2015-0171

Johnson, D. (2013). Ethical indices: how do you measure ethics? Reuters Event: Sustainable Business, 10. https://www.reutersevents.com/sustainability/business-strategy/ethicalindices-how-do-you-measure-ethics

Kuznets, S. (1941). The Structure of the American Economy, 1919-1929. By Wassily W. Leontief. Cambridge: Harvard University Press, 1941. Pp. xi, 181. \$2.50. The Journal of Economic History. https://doi.org/10.1017/s0022050700053158

Kuznets, S. S. (1941). HANSEN, ALVIN H. Fiscal Policy and Busi ness Cycles. Pp. 462. New 
York: W. W. Norton \& Co., 1941. \$3.75. The ANNALS of the American Academy of Political and Social Science. https://doi.org/10.1177/000271624121700181

Lambsdorff, J. G. (2017). Corruption Perceptions Index 2005. In Global Corruption Report 2006. https://doi.org/10.2307/j.ctt184qq53.61

Lee, D. D., \& Faff, R. W. (2009). Corporate Sustainability Performance and Idiosyncratic Risk: A Global Perspective. Financial Review, 44(2), 213-237. https://doi.org/10.1111/j.15406288.2009.00216.x

Mandeville, B. (2011). The fable of the bees: Private vices, publick benefits. In The fable of the bees: Private vices, publick benefits. https://doi.org/10.1037/13124-000

Marx, K. (1867). Das Kapital, Volume 1. In The Marx-Engels Reader.

Marx, K. (2015). Capital: A Critique of Political Economy. Progress Publishers. https://www.marxists.org/archive/marx/works/download/pdf/Capital-Volume-I.pdf

Marx, K., Engels, F., Isaac, J. C., Lukes, S., Bronner, S. E., Tismaneanu, V., \& Sassen, S. (2012). The Communist Manifesto. In The Communist Manifesto. Yale University Press. https://doi.org/10.7202/1023605ar

Narbekovas, A., \& Meilius, K. (2004). Why is the ethics of euthanasia wrong? - PubMed. Med Etika Bioet., 11(3-4), 2-6. https://pubmed.ncbi.nlm.nih.gov/16294446/

Our World in Data. (2020). Our World in Data. https://ourworldindata.org/

Perloff, J. (1998). Microeconomics. Pearson.

Rayman, R. A., \& Rayman, R. A. (2019). Bernard Mandeville (1670- 1733). In Economics Through the Looking-Glass. https://doi.org/10.4324/9780429444586-44

Ricardo, D. (2005). From The Principles of Political Economy and Taxation . https://doi.org/10.1142/9789812701275_0014

Rjazanov, D. (1928). Marx-Engels Archiv, Zeitschrift des Marx-Engels Instituts in Moskau. The American Historical Review, 33(4), 871. https://doi.org/10.2307/1838394

Roberts, J. M. (1995). New Keynesian Economics and the Phillips Curve. Journal of Money, Credit and Banking. https://doi.org/10.2307/2077783

Rodgers, S., \& Rodgers, C. (1989). Business and the Facts af Family Life. Havard Business Review.

Roth, R., Kopf, E., Vollgraf, C.-E., Schefold, B., \& Hubmann, G. (2017). Karl Marx: Das Kapital. Kritik der politischen Ökonomie. Dritter Band. In Karl Marx: Das Kapital. Kritik der politischen Ökonomie. Dritter Band. https://doi.org/10.1515/9783050063645

Shemetev, A. (2020). $R$ Package alexandershemetev (1.0; p. 16). GitHiub. https://github.com/Alexandershemetev/alexandershemetev

Sims, C. A. (2010). But Economics Is Not an Experimental Science. Journal of Economic Perspectives, 24(2), 59-68. https://doi.org/10.1257/jep.24.2.59

Sims, E. R., Wu, J. C., \& Zhang, J. (2020). The Four Equation New Keynesian Model. SSRN Electronic Journal. https://doi.org/10.2139/ssrn.3625622

Smith, A. (1761). Theory of Moral Sentiments (2nd ed.). A. Millar; A. Kincaid \& J. Bell. https://books.google.com/books?id=bZhZAAAAcAAJ\&q=editions\%3Au_L0P5LRqXk $\mathrm{C} \& \mathrm{pg}=\mathrm{PP} 3$

Smith, A. (1776). An inquiry into the wealth of nations. Strahan and Cadell, London.

Smith, J. G. (1942). KUZNETS, SIMON. National Income and Its Composition, 1919-1938. Vol. I, pp. xxx, 387; Vol. II, 388-929. New York: National Bureau of Economic Research, 1941. \$5.00. The ANNALS of the American Academy of Political and Social Science. https://doi.org/10.1177/000271624222100161

Smith, V. L. (1998). The Two Faces of Adam Smith. Southern Economic Journal, 65(1), 1. https://doi.org/10.2307/1061349

Standard Ethics. (2021). Standard Index. https://www.standardethicsindices.eu/indices.html 
Stiglitz, J. E. (2005). The Ethical Economist. Growth may be everything, but it's not the only thing. Review Essay of "The Moral Consequences of Economic Growth by B.M. Friedman", Knopf, 2005. Foreign Affaires.

Transparency International. (2020). Corruption Perceptions Index (CPI). https://www.transparency.org/en/cpi/2020/index/nzl

Troinitsky, A. G. (1858). O čisle krepostnych ludej v Rossii. Typographya Ministerstva Vnitr. del. https://elib.rgo.ru/handle/123456789/227409

UNDP. (2020). United Nations Development Program: Human Development Reports. http://hdr.undp.org/en/content/human-development-index-hdi

United Nations Development Programme. (2021a). Education index. http://hdr.undp.org/en/indicators/103706

United Nations Development Programme. (2021b). Natural resource depletion (\% of GNI). http://hdr.undp.org/en/indicators/97306

Varlamov, I. (2021a). Afghanskaya vojna: reportaž iz Kabula. https://www.youtube.com/watch?v=WN4ml14HkRU

Varlamov, I. (2021b). Kabul, Afghanistan: stolitsa radikalov, musora i zaborov: gorod, otkuda možno ne vernutsja živim. https://www.youtube.com/watch? $=\mathrm{XlWt0hxbBGQ}$

Varlamov, I. (2021c). Proizvodstvo problem na export: vo vse tjažkiě v žizni, a ne v seriale. https://www.youtube.com/watch?v=N5qyIt5xPaU

Wendling, Z. A., Emerson, J. W., de Sherbinin, A., \& Esty, D. C. (2020). Environmental Performance Index. epi.yale.edu

Williamson, J. (2018). Macroeconomics. Pearson.

World Bank. (2020). World Bank Databases. https://databank.worldbank.org/databases 